\title{
Pendidikan Kesehatan Reproduksi Formal dan Hubungan Seksual Pranikah Remaja Indonesia
}

\author{
Formal Reproductive Health Education and Premarital Sexual Intercourse \\ among Indonesian Teenagers
}

\author{
Anggriyani Wahyu Pinandari*, Siswanto Agus Wilopo**, Djauhar Ismail***
}

\begin{abstract}
*Pusat Kesehatan Reproduksi Fakultas Kedokteran, Universitas Gadjah Mada, Indonesia, **Departemen Biostatistik, Epidemiologi dan Kesehatan Populasi Fakultas Kedokteran, Universitas Gadjah Mada, Indonesia, ***:Departemen Pediatrik Fakultas Kedokteran, Universitas Gadjah Mada, Indonesia
\end{abstract}

\begin{abstract}
Abstrak
Transisi demografi kedua akan terjadi di Indonesia dan ditandai dengan revolusi seksual dan reproduksi. Masalah potensial di masa ini adalah peningkatan perilaku seksual pranikah, kehamilan yang tidak diinginkan, infeksi menular seksual dan penyalahgunaan obat. Penelitian ini bertujuan untuk menguji pengaruh pendidikan kesehatan reproduksi formal terhadap penundaan hubungan seksual pranikah pada remaja dan dewasa muda Indonesia. Penelitian potong lintang yang dianalisis sebagai kohort retrospektif menggunakan data Survei Kesehatan Reproduksi Remaja Indonesia tahun 2012 (10.980 laki-laki dan 8.902 perempuan). Efek pendidikan kesehatan reproduksi formal terhadap penundaan perilaku hubungan seksual dianalisis menggunakan kurva kaplan meier, uji log-rank, dan uji kai kuadrat, sedangkan analisis multivariabel menggunakan regresi logistik. Semua tes menggunakan tingkat kepercayaan $95 \%$ dan nilai $p=0,05$. Hasil analisis keberlangsungan berpantang melakukan hubungan seksual pranikah menunjukkan bahwa remaja yang tidak menerima atau hanya menerima salah satu dari materi pendidikan kesehatan reproduksi memiliki hazard ratio yang lebih besar (berturut-turut 1,55 ( $\mathrm{Cl}=1,32-1,82) ; 0,99$ $(\mathrm{Cl}=0,86-1,15)$ dan 2,26 ( $\mathrm{Cl}=1,43-3,56)$. Menerima informasi secara lengkap memberikan waktu berpantang yang lebih lama. Penyalahgunaan obat, merokok, minum alkohol, laki-laki, berusia 20 - 24 tahun dan miskin berpeluang lebih besar untuk melakukan hubungan seksual pranikah. Penerimaan informasi kesehatan reproduksi pada jenjang pendidikan formal dapat menunda terjadinya hubungan seksual pranikah.
\end{abstract}

Kata kunci: Pendidikan kesehatan reproduksi formal, perilaku seksual pranikah, remaja

\section{Abstract}

The second demographic transition will occur in Indonesia and be marked by sexual and reproductive revolution. Potential problems in this era are the increase of premarital sexual behavior, unwanted pregnancy, sexual transmitted infection and drug abuse. This study aimed to examine the influence of formal reproductive health education to delay premarital sexual intercourse among Indonesian teenagers and young adults. Cross-sectional study analyzed as retrospective cohort used data of Indonesian Teenage Reproductive Health Survey in 2012 (10,980 men and 8,902 women). Effects of formal reproductive health education to delay sexual intercourse behavior was analyzed using kaplan meier curve, log-rank test, and chisquare test, meanwhile multivariat analysis used logistic regression. All tests used confidence interval $95 \%$ and $p$ value $=0.05$. Results of survival analysis of abstinence committing sexual intercourse showed that teenagers who did not receive or only receive one of reproductive health education materials had bigger hazard ratio (respectively $1.55(\mathrm{Cl}=1.32-1.82) ; 0.99$ $(\mathrm{Cl}=0.86-1.15)$ and $2.26(\mathrm{Cl}=1.43-3.56))$. Receiving complete information gave longer abstinence time. Drug abuse, smoking, alcohol, men, aged between $20-24$ years old and poor were more likely to commit premarital sexual intercourse. Receipt of reproductive health information at formal education level may delay the occurrence of premarital sexual intercourse.

Keywords: Formal reproductive health education, premarital sexual behavior, teenager

\section{Pendahuluan}

Indonesia akan mengalami transisi demografi pertama dengan angka total fertility rate (TFR) mendekati 2 dan angka kematian yang rendah di penghujung dekade ini. ${ }^{1}$ Fenomena selanjutnya adalah transisi demografi kedua yang ditandai dengan terjadinya revolusi seksual dan reproduksi. Revolusi ini akan menjadi masalah bangsa yang tidak dapat dihindari kecuali berupaya mencegah dampak negatifnya agar tidak semakin parah. ${ }^{2}$ Dua

Korespondensi: Anggriyani Wahyu Pinandari, Pusat Kesehatan Reproduksi FK UGM, Gedung IKM FK UGM Lt.1 Sayap Timur, Jl. Farmako Sekip Utara Yogyakarta, No.Telp: 0274 - 565074, e-mail: aang.pinandari@gmail.com 
fenomena pokok yang terjadi pada transisi demografi kedua adalah angka fertilitas yang terus turun dan perubahan perilaku seksualitas dan reproduksi. ${ }^{3,4}$ Beberapa prediksi terkait dengan situasi ini adalah revolusi seksual dan reproduksi yang mulai telah terjadi di beberapa kota besar yang mengikuti tren negara barat.

Institusi publik dan masyarakat akan semakin sulit mengendalikan perilaku seksual dan reproduksi dalam era globalisasi, khususnya meluasnya penggunaan teknologi komunikasi elektronik, meningkatnya angka hubungan seksual pranikah, kehamilan usia remaja dan infeksi human immunodeficiency virus (HIV) yang diiringi penggunaan obat-obat terlarang dan lain-lain. ${ }^{5}$ Apabila jumlah remaja Indonesia tahun 2010 adalah 64 juta jiwa $(27,6 \%)$ yang berarti satu dari empat penduduk Indonesia adalah remaja, maka risiko kesehatan pada penduduk kelompok usia ini akan sangat memengaruhi kesehatan populasi di masa yang akan datang. ${ }^{6}$

Perilaku seksual yang berisiko, merokok, penyalahgunaan obat, dan kekerasan fisik berhubungan dengan kehamilan pertama pada remaja. ${ }^{7}$ Kehamilan dan persalinan pada remaja akan berakibat pada meningkatnya masalah kesehatan dan memburuknya indikator kesehatan seksual remaja. ${ }^{8}$ Laporan Survei Demografi dan Kesehatan Indonesia (SDKI) tahun 2012 subsurvei Kesehatan Reproduksi Remaja (KRR), menyebutkan bahwa hubungan seksual pranikah pada remaja perempuan sebesar $1 \%$ dan remaja laki-laki $8,3 \% .{ }^{9}$ Khusus untuk remaja laki-laki, persentase hubungan seksual pranikah meningkat sebesar 1,9\% dibandingkan dengan Survei Kesehatan Reproduksi Remaja Indonesia (SKRRI) tahun 2007.10 Secara biologis, sistem imun dan reproduksi yang belum matang pada remaja perempuan akan meningkatkan kemungkinan untuk terpapar infeksi menular seksual (IMS) dan HIV.11,12 Di tahun 2009, $40 \%$ kasus baru HIV pada kelompok remaja berasal dari usia 15 - 24 tahun dan setiap hari lebih dari 2.400 kaum muda terinfeksi serta terdapat lebih dari 5 juta kaum muda yang menderita HIV/AIDS. ${ }^{13}$ Data menunjukkan bahwa infeksi human papilloma virus (HPV) pada alat genital meningkat setelah memulai aktivitas seksual dengan insiden kumulatif infeksi HPV sebesar $50-80 \%$ dalam dua sampai tiga tahun setelah hubungan seksual pertama kali. ${ }^{14}$

Penundaan hubungan seksual pertama kali menjadi strategi yang sangat penting untuk mengurangi risiko negatif dari buruknya indikator kesehatan seksual remaja. ${ }^{15}$ Hubungan seksual yang terlalu dini berkaitan dengan kejadian IMS, kehamilan yang tidak terencana, depresi, putus sekolah, memiliki pasangan seksual lebih dari satu dan hubungan seksual yang tidak terlindungi (tanpa penggunaan alat kontrasepsi). Penelitian lain yang dilakukan di Jakarta, Tangerang, dan Bekasi juga menemukan bahwa remaja usia 17 - 24 tahun yang menjadi sampel, 20,9\% pernah mengalami kehamilan dan kelahiran sebelum menikah dan 38,7\% pernah mengalami kehamilan sebelum menikah dan kelahiran setelah menikah.

Teori model ekologis terbaru yang menjelaskan perilaku kesehatan berisiko remaja menyebutkan bahwa perilaku adalah hasil dari interaksi antara manusia dan lingkungan sekitar seperti sekolah, teman sebaya, dan keluarga. ${ }^{16}$ Mengacu pada teori tersebut, media massa adalah bagian penting lainnya yang lebih luas dari kehidupan kaum muda yang dapat memberikan pengaruh signifikan selama usia remaja, khususnya perilaku seksual berisiko. ${ }^{17,18}$ SKRRI tahun 2007 menyebutkan bahwa guru merupakan sumber utama untuk mendapatkan informasi perubahan fisik saat pubertas, sedangkan media cetak dan televisi merupakan sumber informasi untuk HIV/AIDS, dan teman merupakan lawan bicara pengalaman menstruasi pertama dan mimpi basah yang paling banyak dipilih oleh remaja. Besarnya pengaruh dimensi ekologis terhadap perilaku seksual remaja tidak diimbangi dengan penelitian tentang pengaruh sumber informasi terhadap perilaku tersebut. ${ }^{19,20}$ Oleh karena itu, penelitian ini menguji pengaruh pemberian informasi kesehatan reproduksi pada jenjang pendidikan formal terhadap perilaku hubungan seksual pranikah remaja dan dewasa muda di Indonesia.

\section{Metode}

SDKI tahun 2012 menggunakan metode pengambilan sampel dalam tiga tahap. Tahap pertama adalah memilih sejumlah primary sampling unit (PSU) dari kerangka sampel PSU yang dibentuk untuk keperluan pelbagai survei dengan pendekatan rumah tangga secara probability proportional to size (PPS). PSU adalah kelompok blok sensus berdekatan yang menjadi wilayah tugas koordinator tim sensus penduduk tahun 2010. Tahap kedua adalah memilih sebuah blok sensus secara PPS di setiap PSU terpilih pada tahap pertama. Tahap ketiga adalah memilih 25 rumah tangga biasa di setiap blok sensus terpilih secara sistematis dari hasil pemutakhiran rumah tangga pada blok sensus terpilih di tahap kedua. Jumlah sampel SDKI 2012 adalah 1.840 blok sensus, 874 blok sensus di daerah perkotaan dan 966 blok sensus.

Penelitian ini merupakan penelitian potong lintang yang menggunakan data SDKI tahun 2012 subsurvei KRR dengan populasi penelitian seluruh remaja dan dewasa muda usia 15 - 24 tahun di Indonesia. Penelitian ini melibatkan responden dalam SDKI 2012 (laki-laki 10.890, perempuan 8.902) yang memenuhi kriteria inklusi, yaitu laki-laki dan perempuan yang berusia 15 24 tahun dan belum menikah. Kriteria eksklusi penelitian ini adalah responden yang melaporkan tidak sekolah dan menjawab tidak tahu pada pertanyaan-pertanyaan 
yang berkaitan dengan variabel penelitian.

Responden yang melaporkan telah melakukan hubungan seksual pranikah menjadi event dan yang tidak menjadi sensor. Pengaruh variabel bebas, yaitu jenis informasi yang diterima remaja saat berada di jenjang pendidikan formal, terhadap variabel terikat yaitu hubungan seksual pranikah dianalisis dengan mempertimbangkan waktu munculnya perilaku tersebut. Pengaruh variabel luar, yaitu konsumsi narkotik, psikotropika, dan zat aditif (napza), alkohol, rokok, tingkat pendidikan, jenis kelamin, usia, tingkat kekayaan dan tipe domisili juga dipertimbangkan dalam analisis multivariabel.

Analisis univariabel dilakukan dengan statistik deskriptif untuk mengetahui sebaran karakteristik subyek penelitian dengan melihat distribusi frekuensi dan proporsi masing-masing kelompok. Analisis bivariabel menggunakan kurva kaplan meier, uji log-rank, dan uji chi square untuk mengetahui hubungan antara variabel bebas dengan variabel terikat dan variabel luar dengan variabel terikat. Pengaruh variabel bebas terhadap variabel terikat dengan mempertimbangkan varibel luar dilakukan pada analisis multivariabel dengan regresi logistik. Keseluruhan analisis menggunakan CI 95\% dan nilai $\mathrm{p}=0,05$.

\section{Hasil}

Kriteria inklusi dan eksklusi penelitian ini mengurangi jumlah sampel menjadi 18.749 orang. Kriteria inklusi dan eksklusi yang diterapkan dapat dilihat pada subbab sampel penelitian. Sampel yang tidak pernah melakukan hubungan seksual pranikah (sensor) berjumlah 17.430 orang $(92,9 \%)$ dan yang pernah melakukan hubungan seksual (event) berjumlah 1.319 orang $(7,0 \%)$.

Tabel 1 menunjukkan beberapa tren perilaku hubungan seksual pranikah berdasarkan karakteristik sosio-demografi. Tingkat kekayaan yang dibagi menjadi lima kategori menunjukkan bahwa semakin baik tingkat kekayaan, semakin kecil jumlah remaja dan dewasa muda yang melakukan hubungan seksual pranikah. Distribusi tertinggi pengalaman hubungan seksual pranikah ditemukan pada responden yang sangat miskin dengan jumlah observasi 304 orang $(23,1 \%)$ dan terendah pada responden yang sangat kaya yaitu sebesar 221 (16,8\%).

Distribusi pengalaman koitus remaja banyak ditemukan pada responden yang berpendidikan akhir sekolah menengah atas (SMA). Persentase koitus meningkat seiring dengan semakin tingginya tingkat pendidikan walaupun terjadi penurunan pada responden yang telah

Tabel 1. Distribusi Frekuensi Perilaku Hubungan Seksual Pranikah Remaja dan Dewasa Muda Menurut Data Sosiodemografi dan Jenis Informasi Pendidikan Formal*

\begin{tabular}{|c|c|c|c|c|c|c|c|}
\hline \multirow{2}{*}{ Karakteristik Responden } & \multirow{2}{*}{ Variabel } & \multicolumn{2}{|c|}{ Tidak Koitus } & \multicolumn{2}{|c|}{ Koitus } & \multicolumn{2}{|c|}{ Total } \\
\hline & & $\mathbf{n}$ & $(\%)$ & $\mathbf{n}$ & $(\%)$ & $\mathbf{n}$ & $(\%)$ \\
\hline \multirow[t]{4}{*}{ Jenis informasi pendidikan formal ${ }^{* * *}$} & Sistem reproduksi & 10.554 & $(60,5)$ & 675 & $(51,2)$ & 11.229 & $(59,8)$ \\
\hline & Metode kontrasepsi & 130 & $(0,8)$ & 20 & $(1,5)$ & 150 & $(0,8)$ \\
\hline & Menerima keduanya & 3.179 & $(18,2)$ & 243 & $(18,4)$ & 3.422 & $(18,3)$ \\
\hline & Tidak menerima keduanya & 3.567 & $(20,5)$ & 381 & $(28,9)$ & 3.948 & $(21,1)$ \\
\hline \multirow{2}{*}{ Napza*** } & Tidak & 17.174 & $(98,5)$ & 1.124 & $(85,2)$ & 18.298 & $(97,6)$ \\
\hline & Ya & 256 & $(1,5)$ & 195 & $(14,8)$ & 451 & $(2,4$ \\
\hline \multirow[t]{2}{*}{ Alkohol $* *$} & Tidak & 13.634 & $(78,2)$ & 286 & $(21,7)$ & 13.920 & $(74,2)$ \\
\hline & Ya & 3.796 & $(21,8)$ & 1.033 & $(78,3)$ & 4.829 & $(25,8)$ \\
\hline \multirow{2}{*}{ Merokok $* *$} & Tidak & 9.559 & $(54,8)$ & 148 & $(11,2)$ & 9.707 & $(51,8)$ \\
\hline & $\mathrm{Ya}$ & 7.871 & $(45,2)$ & 1.171 & $(88,8)$ & 9.042 & $(48,2)$ \\
\hline \multirow[t]{4}{*}{ Tingkat pendidikan $* *$} & $\mathrm{SD}$ & 1.516 & $(8,7)$ & 159 & $(12,0)$ & 1.675 & $(8,9)$ \\
\hline & SMP & 4.161 & $(23,9)$ & 236 & $(17,9)$ & 4.397 & $(23,5)$ \\
\hline & SMA & 8.786 & $(50,4)$ & 631 & $(47,8)$ & 9.417 & $(50,2)$ \\
\hline & Diploma/PT & 2.967 & $(17,0)$ & 293 & $(22,3)$ & 3.260 & $(17,4)$ \\
\hline \multirow[t]{2}{*}{ Jenis kelamin $* *$} & Laki-Laki & 8.886 & $(60,0)$ & 1.188 & $(90,1)$ & 10.074 & $(53,7)$ \\
\hline & Perempuan & 8.544 & $(49,0)$ & 131 & $(9,9)$ & 8.675 & $(46,3)$ \\
\hline \multirow[t]{2}{*}{ Usia $(\min =15, \max =24, \text { mean }=19)^{* * *}$} & Remaja & 11.774 & $(67,5)$ & 462 & $(35,0)$ & 12.236 & $(65,3)$ \\
\hline & Dewasa muda & 5.656 & $(32,5)$ & 857 & $(65,0)$ & 6.513 & $(34,7)$ \\
\hline \multirow[t]{5}{*}{ Tingkat kekayaan ${ }^{* * *}$} & Sangat miskin & 3.177 & $(18,2)$ & 304 & $(23,1)$ & 3.481 & $(18,6)$ \\
\hline & Miskin & 3.489 & $(20,0)$ & 288 & $(21,8)$ & 3.777 & $(20,1)$ \\
\hline & Menengah & 3.605 & $(20,7)$ & 273 & $(20,7)$ & 3.878 & $(20,7)$ \\
\hline & Kaya & 3.366 & $(19,3)$ & 233 & $(17,7)$ & 3.599 & $(19,2)$ \\
\hline & Sangat kaya & 3.793 & $(21,8)$ & 221 & $(16,8)$ & 4.041 & $(21,4)$ \\
\hline \multirow[t]{2}{*}{ Tempat tinggal $^{* * *}$} & Perkotaan & 10.049 & $(57,7)$ & 771 & $(58,5)$ & 10.820 & $(57,7)$ \\
\hline & Pedesaan & 7.381 & $(42,3)$ & 548 & $(41,5)$ & 7.929 & $(42,3)$ \\
\hline Total $(\mathrm{n}=18.749)$ & & 17.430 & $(100)$ & 1.319 & $(100)$ & 18.749 & $(100)$ \\
\hline
\end{tabular}

Keterangan:

* data tidak tertimbang; $* *$ variabel pada level individu; ${ }^{* * *}$ variabel pada level keluarga. 
berpendidikan tinggi. Selain itu, berdasarkan kategori usia saat dilakukan survei, distribusi pengalaman koitus lebih banyak ditemukan pada kategori usia 20 - 24 tahun atau dewasa muda dibandingkan dengan 15 - 19 tahun atau remaja.

Penelitian ini juga mempertimbangkan perilaku berisiko remaja dan dewasa muda. Responden yang merokok, minum alkohol, dan mengonsumsi napza memiliki persentase pengalaman koitus yang lebih tinggi dibandingkan dengan yang tidak. Sedangkan menurut domisili, responden yang tinggal di perkotaan memiliki persentase pengalaman koitus yang lebih besar dibandingkan dengan responden yang tinggal di pedesaan. Distribusi variabel bebas yaitu jenis informasi kesehatan reproduksi yang didapatkan di jenjang pendidikan formal bervariasi. Tabel 1 menunjukkan persentase pengalaman koitus tertinggi ditemukan pada kelompok responden yang hanya menerima informasi sistem reproduksi $(51,2 \%)$ dan terendah pada responden yang menerima informasi metode kontrasepsi $(1,5 \%)$. Sedangkan menurut jenis kelamin, remaja dan dewasa muda laki-laki lebih banyak melaporkan pengalaman koitus dibandingkan dengan perempuan.

Gambar 1 menunjukkan bahwa responden yang menerima informasi kesehatan reproduksi yang komprehensif, meliputi sistem reproduksi dan metode kontrasepsi, memiliki probabilitas kelangsungan berpantang melakukan hubungan seksual pranikah yang paling baik $(80,0 \%)$ dibandingkan dengan kategori lain. Probabilitas terendah ditemukan pada responden yang hanya menerima informasi metode kontrasepsi di jenjang pendidikan formal $(76,2 \%)$. Sejalan dengan pola survival yang ditampilkan oleh kurva kaplan-meier, signifikansi pendidikan kesehatan reproduksi formal menurut kategori menunjukan bahwa remaja dan dewasa muda yang hanya menerima informasi metode kontrasepsi atau bahkan tidak menerima informasi apapun secara signifikan berisiko lebih besar untuk melakukan hubungan seksual pranikah.

Variabel individu lain yang berpengaruh terhadap perilaku hubungan seksual pranikah remaja dan dewasa muda adalah konsumsi napza, alkohol dan rokok, jenis kelamin laki-laki serta berusia 20 - 24 tahun (dewasa muda). Remaja dan dewasa muda yang berpendidikan tinggi lebih berpeluang melakukan hubungan seksual pranikah dibanding yang berpendidikan sekolah menengah pertama (SMP) dan SMA. Namun, berpendidikan sekolah dasar (SD) ternyata justru meningkatkan peluang hubungan seksual pranikah sebesar 6\% dibandingkan dengan berpendidikan tinggi walaupun peningkatan ini tidak berbeda secara statistik.

Pengaruh tingkat kekayaan dalam memprediksi peluang melakukan hubungan seksual pranikah remaja dan dewasa muda menunjukkan bahwa remaja dan dewasa

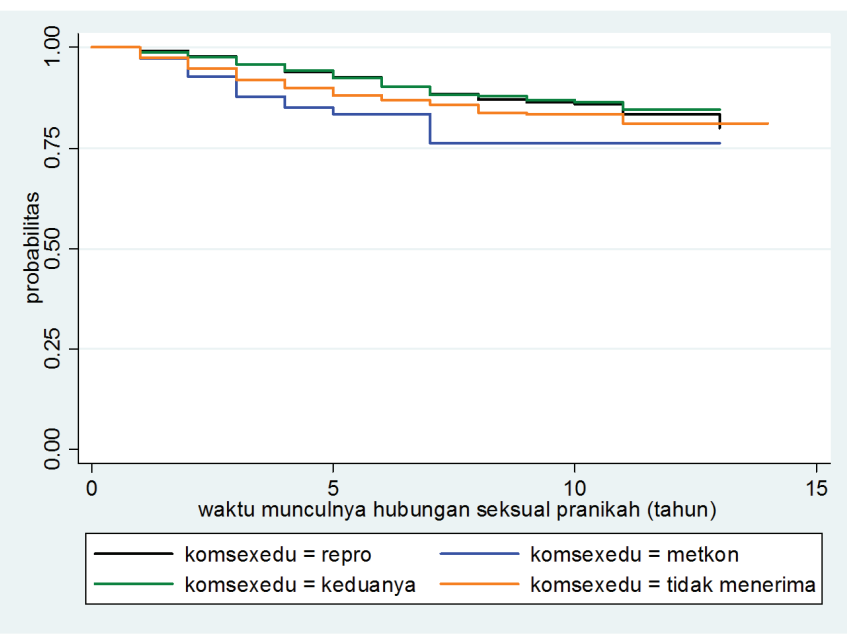

Gambar 1. Kurva Kaplan-Meier Munculnya Hubungan Seksual Pranikah Berdasarkan Jenis Informasi Kesehatan Reproduksi Formal

muda yang berada pada $60 \%$ kuintil terbawah atau sangat miskin, miskin dan menengah secara signifikan lebih mungkin untuk melakukan hubungan seksual pranikah dibandingkan dengan yang sangat kaya. Sedangkan remaja dan dewasa muda yang kaya memiliki kemungkinan 1,18 kali lebih besar melakukan hubungan seksual dibandingkan dengan yang sangat kaya. Namun, efek ini tidak bermakna secara statistik. Tinggal di perkotaan secara signifikan tidak berpengaruh terhadap peluang terjadinya hubungan seksual pranikah pada remaja dan dewasa muda di Indonesia. Pola signifikansi pengaruh ini tidak banyak berubah pada analisis multivariabel (Tabel 2).

\section{Pembahasan}

Secara umum, terjadi peningkatan prevalensi hubungan seksual pranikah pada SDKI periode 2007 dibandingkan periode 2012 mencapai 1,9\% pada remaja lakilaki walaupun angkanya cenderung konstan pada remaja perempuan. ${ }^{21}$ Penelitian ini memberikan gambaran baru tentang pengalaman hubungan seksual pranikah remaja dan dewasa muda terjadi di Indonesia berdasarkan kontribusi tiga level variabel yaitu individu, kabupaten, dan provinsi. Prevalensi pengalaman berhubungan seksual pranikah remaja dan dewasa muda di Indonesia menurut SDKI 2012 bervariasi antarwilayah. Wellings et al, 22 berpendapat variasi tersebut dapat disebabkan oleh beberapa faktor, seperti lingkungan termasuk di dalamnya kemiskinan, pendidikan, dan pekerjaan. Kebijakan, kemajuan dalam kontrasepsi, dan akses pelayanan keluarga berencana serta strategi pencegahan HIV dan IMS juga ikut berperan dalam variasi ini. Faktor berikutnya yang memengaruhi variasi hubungan seksual pranikah remaja dan dewasa muda, yaitu tren demografi seperti perubahan struktur usia populasi penduduk, usia menikah yang semakin tua, peningkatan migrasi antar dan dalam ne- 
Tabel 2. Hasil Analisis Bivariabel dan Multivariabel

\begin{tabular}{|c|c|c|c|c|c|c|}
\hline \multirow{2}{*}{ Karakteristik Responden } & \multirow{2}{*}{ Kategori } & \multirow{2}{*}{$\begin{array}{c}\text { Survival } \\
\text { Function } \\
(\%)\end{array}$} & \multicolumn{2}{|c|}{ Unadjusted Model } & \multicolumn{2}{|c|}{ Adjusted Model } \\
\hline & & & Nilai $p^{*}$ & $\mathrm{HR} / \mathrm{PR}(\mathrm{CI}) \#$ & Nilai $p^{*}$ & OR (CI) \\
\hline \multirow[t]{4}{*}{ Jenis informasi pendidikan formal*** } & Sistem reproduksi & 80,0 & 0,00 & $0,99(0,86-1,15)$ & 0,26 & $0,91(0,77-1,07)$ \\
\hline & Metode kontrasepsi & 76,2 & & $2,26(1,43-3,56)^{*}$ & 0,12 & $1,56(0,89-2,73)$ \\
\hline & Menerima keduanya $r e f$ & 84,5 & & 1 & - & 1 \\
\hline & Tidak menerima keduanya & 81,1 & & $1,55(1,32-1,82)^{*}$ & $0,00 *$ & $1,58(1,29-1,93)$ \\
\hline \multirow[t]{2}{*}{$\mathrm{Napza}^{* * *}$} & Ya & & 0,00 & $7,04(6,24-7,94)^{*}$ & $0,00 *$ & $3,17(2,56-3,92)$ \\
\hline & Tidak & & & 1 & & 1 \\
\hline \multirow[t]{2}{*}{ Alkohol $^{* * *}$} & Ya & & 0,00 & $10,41(9,17-11,82)^{*}$ & $0,00 *$ & $5,58(4,77-6,51)$ \\
\hline & Tidak & & & 1 & & 1 \\
\hline \multirow[t]{2}{*}{ Merokok ${ }^{* * *}$} & Ya & & 0,00 & $8,49(7,18-10,05)^{*}$ & $0,00 *$ & $2,04(1,62-2,57)$ \\
\hline & Tidak & & & 1 & & 1 \\
\hline \multirow[t]{4}{*}{ Tingkat pendidikan*** } & $\mathrm{SD}$ & & 0,00 & $1,06(0,88-1,27)$ & $0,00 *$ & $0,52(0,40-0,68)$ \\
\hline & SMP & & & $0,59(0,51-0,70)^{*}$ & $0,00 *$ & $0,56(0,45-0,69)$ \\
\hline & SMA & & & $0,75(0,65-0,85)^{*}$ & $0,02 *$ & $0,81(0,68-0,97)$ \\
\hline & Diploma/PT ref & & & 1 & - & 1 \\
\hline \multirow[t]{2}{*}{ Jenis kelamin ${ }^{* * *}$} & Laki-Laki & & 0,00 & $7,81(6,54-9,33)^{*}$ & $0,00 *$ & $2,03(1,59-2,59)$ \\
\hline & Perempuan & & & 1 & & 1 \\
\hline \multirow[t]{2}{*}{$\mathrm{Usia}^{* * *}$} & Dewasa muda & & 0,00 & $3,48(3,12-3,89)^{*}$ & $0,00 *$ & $2,39(2,09-2,74)$ \\
\hline & Remaja & & & 1 & & 1 \\
\hline \multirow[t]{5}{*}{ Tingkat kekayaan ${ }^{* * *}$} & Sangat miskin & & 0,00 & $1,58(1,34-1,87)^{*}$ & $0,00 *$ & $1,97(1,57-2,47)$ \\
\hline & Miskin & & & $1,38(1,17-1,64)^{*}$ & $0,00 *$ & $1,57(1,28-1,94)$ \\
\hline & Menengah & & & $1,28(1,08-1,52)^{*}$ & $0,02 *$ & $1,28(1,04-1,58)$ \\
\hline & Kaya & & & $1,18(0,98-1,41)$ & 0,07 & $1,21(0,99-1,49)$ \\
\hline & Sangat kaya $r e f$ & & & 1 & - & 1 \\
\hline \multirow[t]{2}{*}{ Tempat tinggal $* * * *$} & Perkotaan & & 0,57 & $0,97(0,87-1,08)$ & 0,77 & $1,02(0,89-1,18)$ \\
\hline & Pedesaan & & & 1 & & 1 \\
\hline
\end{tabular}

Keterangan :

* signifikansi $(\mathrm{p}<0,05)$, dihitung menggunakan uji log-rank atau $\mathrm{X}^{2}$; \#hazard ratio (HR) dihitung dengan uji cox regression, prevalence ratio $(\mathrm{PR})$;

** variabel pada level individu; *** variabel pada level keluarga; ref: referensi; hasil uji regresi logistik.

gara serta globalisasi media massa. ${ }^{5}$

Pengaruh usia dan penundaan usia menikah tersebut sejalan dengan hasil analisis kontribusi variabel level individu yang menunjukkan bahwa peluang pengalaman hubungan seksual pranikah lebih besar pada responden dewasa muda. Dibandingkan dengan remaja, dewasa muda memiliki jarak yang lebih panjang antara usia pubertas dan menikah sehingga menyebabkan risiko kesehatan seksual yang muncul semakin besar seperti meningkatnya proporsi hubungan seksual pranikah. ${ }^{23}$ Secara teoritis, peningkatan hormon testosteron yang terjadi selama masa pubertas berhubungan dengan waktu inisiasi hubungan seksual dan frekuensi hubungan seksual remaja laki-laki. ${ }^{24}$ Sedangkan pada remaja perempuan, hormon testosteron berhubungan dengan peningkatan minat dan aktivitas seksual. ${ }^{25} \mathrm{Hal}$ ini akan mengarah pada meningkatnya hasrat keintiman dan hubungan seks serta daya pikat seksual.

Lebih lanjut, apabila membandingkan peluang terjadinya hubungan seksual menurut jenis kelamin, laki-laki berpeluang lebih besar untuk melakukan hubungan seksual pranikah dibandingkan perempuan. Temuan ini sejalan dengan penelitian yang dilakukan oleh Komang Y Rahyani, ${ }^{26}$ pada remaja di Bali tahun 2012. Di negara dengan perbedaan prevalensi hubungan seksual pranikah yang besar antara laki-laki dan perempuan (Indonesia, berdasarkan SDKI 2012 prevalensi hubungan seksual pranikah laki-laki dan perempuan berturut-turut 8,3\% dan $1 \%$ ), perbedaan risiko tersebut dikarenakan remaja dan dewasa muda laki-laki lebih mungkin untuk melaporkan pengalaman hubungan seksual pranikah dengan pekerja seks. ${ }^{22}$ Menurut Wellings et al, ${ }^{21}$ proporsi tersebut berkisar antara 1 - 14\%. Di Indonesia pada tahun 2012, proporsi remaja laki-laki yang melaporkan pernah berhubungan seksual dengan perempuan pekerja seks mencapai angka 3,71\%.

Perilaku berisiko lain yang meningkatkan kemungkinan terjadinya hubungan seksual pranikah adalah merokok, mengonsumsi alkohol, dan napza. Temuan ini sejalan dengan hipotesis penelitian yang dilakukan oleh Boislard dan Poulin, ${ }^{27}$ yang menyebutkan bahwa remaja yang terlibat dalam perilaku berisiko seperti penyalahgunaan obat-obatan dan perilaku antisosial seringkali juga melakukan hubungan seksual pada usia dini. Menurut Irwin dan Millstein dalam buku adolescent health: understanding and preventing risk behavior, perilaku berisiko remaja merupakan manifestasi dari asynchronous pubertal maturation atau kematangan yang terlalu cepat/lambat dari sebaya. Kondisi ini memungkinkan remaja untuk terlibat dalam perilaku-perilaku orang dewasa seperti merokok, minum alkohol, mengonsumsi obat-obatan bahkan melakukan hubungan seksual 
pranikah. Perilaku-perilaku tersebut mungkin juga merupakan hasil dari pengaruh kelompok usia yang lebih dewasa di sekitar mereka yang secara normatif menerima perilaku tersebut. ${ }^{28}$

Perilaku berisiko banyak ditemukan pada tipe domisili perkotaan, namun secara statistik pengaruh tipe domisili terhadap perilaku hubungan seksual tidak signifikan, baik pada uji bivariabel maupun multilevel. Levine et al, ${ }^{29}$ juga menemukan bahwa status metropolitan tidak berdampak signifikan terhadap perilaku seksual berisiko remaja. Dari sudut pandang populasi, status domisili memberikan pengaruh yang kecil dalam memprediksi perilaku seksual dikarenakan pengaruhnya bergabung dengan pengaruh ras atau etnis, kemiskinan, dan karakteristik lain seperti moral, tabu, hukum, dan kepercayaan agama yang digunakan oleh masyarakat luas untuk membatasi dan mendefinisikan perilaku seksual di masyarakat yang bersangkutan. ${ }^{22}$ Itulah alasan analisis perilaku berisiko remaja seharusnya mengkaji lebih dekat aspek-aspek lingkungan, baik mikro maupun makro, untuk mengetahui karakteristik yang memengaruhi perilaku tersebut. ${ }^{29}$

Institusi formal seperti pendidikan juga merupakan bagian dari struktur sosial makro yang memengaruhi perilaku individu. Analisis bivariabel menunjukkan bahwa tingkat pendidikan berhubungan dengan peluang terjadinya hubungan seksual pranikah remaja dan dewasa muda di Indonesia. Temuan utama dari penelitian ini, yaitu keberlangsungan berpantang melakukan hubungan seksual pranikah menunjukkan bahwa remaja dan dewasa muda tidak menerima pedidikan kesehatan reproduksi formal atau hanya menerima informasi metode kontrasepsi, berpeluang semakin besar untuk melakukan hubungan seksual pranikah dari waktu ke waktu. Menerima informasi kesehatan reproduksi yang komprehensif (sistem reproduksi dan metode kontrasepsi) memberikan peluang waktu berpantang melakukan hubungan seksual pranikah yang paling lama. Temuan ini sejalan dengan beberapa tinjauan penelitian terdahulu yang menyebutkan bahwa pendidikan seksual yang berbasis sekolah mampu menunda hubungan seksual yang terlalu dini dan meningkatkan keefektifan diri serta niat untuk berperilaku seks yang aman. ${ }^{22,30}$ Maka, menjadikan pendidikan kesehatan reproduksi komprehensif sebagai bagian dari kurikulum pendidikan formal merupakan sebuah keharusan di Indonesia.

\section{Kesimpulan}

Remaja dan dewasa muda yang menerima informasi kesehatan reproduksi komprehensif (kesehatan reproduksi dan metode kontrasepsi) pada jenjang pendidikan formal memiliki kemungkinan lebih kecil untuk melakukan hubungan seksual pranikah. Keberlangsungan berpantang melakukan hubungan seksual pranikah juga remaja dan dewasa muda yang tidak menerima pedidikan kesehatan reproduksi formal atau hanya menerima informasi metode kontrasepsi semakin kecil dari waktu ke waktu. Menerima informasi kesehatan reproduksi yang komprehensif memberikan peluang yang lebih besar kepada remaja dan dewasa muda untuk menunda hubungan seksual pranikah.

\section{Daftar Pustaka}

1. United Nation. World population prospect: the 2010 revision, volume I: comprehensive tables. New York: United Nation; 2011.

2. Wilopo SA. Pengaruh perkembangan teknologi kontrasepsi pada transisi demografi kedua dan implikasinya bagi dokter kesehatan masyarakat kedepan. Yogyakarta: Universitas Gadjah Mada; 2013.

3. Sutton M. The second demographic transition: is there a conventional wisdom? Zeithschrift fur Bevolkerungswissenschaft. 2009; 33: 247-70.

4. Van de Kaa DJ. The idea of a second demographic transition in industrialized countries. The sixth Welfare Policy Seminar of The National Institute of Population and Social Security [manuscript on internet]. 2002 Jan 29 [cited 2015 Feb 5], Tokyo, Japan. Available from: http://virtualpostgrados.unisabana.edu.co/pluginfile.php /163483/mod_resource/content/5/kaa\%281\%29\%20second\%20demographic\%20transition.pdf

5. Wilopo SA. Kesehatan perempuan: prioritas agenda pembangunan kesehatan di abad ke-21. Yogyakarta: Pusat Kesehatan Reproduksi; 2010.

6. BPS. Sensus penduduk 2010. Jakarta: Badan Pusat Statistik; 2010.

7. Cavazos-Rehg PA, Krauss MJ, Spitznagel EL, Schootman M, Cottler LB, Bierut LJ. Associations between multiple pregnancies and health risk behaviors among U.S. Adolescents. The Journal of Adolescent Health. 2010; 47 (6): 600-3.

8. Bearinger LH, Sieving RE, Ferguson J, Sharma V. Global perspectives on the sexual and reproductive health of adolescents: patterns, prevention, and potential. Lancet. 2007; 369 (9568): 1220-31.

9. BPS. Survei demografi dan kesehatan indonesia 2012 kesehatan reproduksi remaja laporan pendahuluan. Jakarta: Badan Pusat Statistik; 2013.

10. BPS. Survey kesehatan reproduksi remaja Indonesia. Jakarta: Badan Pusat Statistik; 2010.

11. Dehne K, Riedner G. Sexually transmitted infections among adolescents: the need for adequate health services. Geneva: World Health Organization; 2005.

12. Mathews C, Aarø LE, Grimsrud A, Flisher AJ, Kaaya S, Onya H, et al. Effects of the SATZ teacher-led school HIV prevention programmes on adolescent sexual behaviour: cluster randomised controlled trials in three sub-Saharan African sites. International Health. 2012; 4 (2): 111 22.

13. WHO. Young people: health risks and solutions. WHO Media centre; 2011 [cited 2013 August 18]. Available from: http://www.who.int/mediacentre/factsheets/fs345/en/.

14. Crochard A, Luyts D, di Nicola S, Gonçalves MAG. Self-reported sexual debut and behavior in young adults aged 18-24 years in seven European countries: implications for HPV vaccination programs. Gynecologic Oncology. 2009; 115 (3 Supplement): S7-14.

15. Cuffee JJ, Hallfors DD, Waller MW. Racial and gender differences in adolescent sexual attitudes and longitudinal associations with coital de- 
but. The Journal of Adolescent Health. 2007; 41 (1): 19-26.

16. Kotchick BA, Shaffer A, Miller KS, Forehand R. Adolescent sexual risk behavior: a multi-system perspective. Clinical Psychology Review. 2001; 21 (4): 493-519.

17. L'Engle K, Brown J, Kenneavy K. The mass media are an important context for adolescents' sexual behavior. The Journal of Adolescent Health. 2006; 38: 186-92.

18. Brown J, Cantor J. An agenda for research on youth and the media. The Journal of adolescent health: official publication of the Society for Adolescent Medicine. 2000; 27 (Suppl 2): 2-7.

19. Guse K, Levine D, Martins S, Lira A, Gaarde J, Westmorland W, et al. Interventions using new digital media to improve adolescent sexual health: a systematic review. The Journal of Adolescent Health. 2012; 51 (6): $535-43$.

20. Lou C, Cheng Y, Emerson MR, Gao E, Zuo XS, Zabin L. Media's contribution to sexual knowledge, attitudes, and behaviors for adolescents and young adults in three asian cities. The Journal of Adolescent Health. 2012; 50: S26-36.

21. BPS, National Population and Family Planning Board (BKKBN), Kementerian Kesehatan (Kemenkes-MOH), ICF International . Indonesia demographic and health survey 2012: adolescent reproductive health. Jakarta: BPS, BKKBN, Kemenkes and ICF International; 2013.

22. Wellings K, Collumbien M, Slaymaker E, Singh S, Hodges Z, Patel D, et al. Sexual behaviour in context: a global perspective. Lancet. 2006; 368 (9548): 1706-28.
23. Kirby D. Risky sexual behavior. In: Editors-in-Chief BBB, Mitchell JP, editors. Encyclopedia of adolescence. San Diego: Academic Press; 2011. p. 264-75.

24. Halpern CT, Udry JR, Suchindran C. Monthly measures of salivary testosterone predict sexual activity in adolescent males. Archive of Sexual Behavior. 1998; 27: 445-65.

25. Halpern CT, Udry JR, Suchindran C. Testosterone predicts initiation of coitus in adolescent females. Psychosomatic Medicine. 1997; 59: 16171.

26. Rahyani YK, Utarini A, Wilopo SA, Hakimi M. Perilaku seks pranikah remaja. Kesmas: Jurnal Kesehatan Masyarakat Nasional. 2012; 7 (4): $180-5$

27. Boislard PM-A, Poulin F. Individual, familial, friends-related and contextual predictors of early sexual intercourse. The Journal of Adolescent Health. 2011; 34 (2): 289-300.

28. DiClemente R, Santelli JS, Crosby RA. Adolescent health: understanding and preventing risk behavior. San Fransisco: Jossey-Bass, A Wiley Imprint; 2009.

29. Levin KA, Dundas R, Miller M, McCartney G. Socioeconomic and geographic inequalities in adolescent smoking: a multilevel cross-sectional study of 15 year olds in Scotland. Social Science \& Medicine. 2014; 107: 162-70.

30. Lazarus JV, Moghaddassi M, Godeau E, Ross J, Vignes C, Östergren PO, et al. A multilevel analysis of condom use among adolescents in the European Union. Public Health. 2009; 123 (2): 138-44. 